\title{
Employing Descriptive and Parametric Statistics to Analyse Entrepreneurship Opportunity As A Catalyst For Youth Employment
}

\author{
Thomas Achoda Omang \\ University of Calabar, P.M.B. 1115, Calabar, Cross River State, Nigeria
}

\begin{abstract}
The study examines how entrepreneurship opportunities have solved the problem of youth employment and underemployment in Calabar South Local Government Area, Cross River State, Nigeria. Adopting the survey research design, data was gathered from four hundred (400) youths from Calabar using cluster, purposive and simple random sampling techniques. The instrument of data collection is a structured questionnaire. The generated data were appropriately coded and analyzed using simple percentages and Multiple Regression Analysis at a 0.05 level of significance. Results show that an entrepreneurship opportunity significantly solves the problem of youth employment and underemployment in Calabar South Local Government Area, Cross River State, Nigeria. The study recommended, among others, that: Skill acquisition program should be organized periodically where talks on entrepreneurship and practical participation will be carried out. Workshop on capacity building and skill acquisition will go a long way to ensure technological advancement and rapid growth/development of the society.
\end{abstract}

Keywords: entrepreneurship opportunities, unemployment, underemployment, parametric statistics.

\section{Introduction}

A challenge that every government find difficult to solve is unemployment and underemployment. These issues have turned into a global phenomenon in the $21^{\text {st }}$ century and are becoming more complex by the passing day, especially among the youth. Data gathered from different nations revealed that the youth unemployment rate is up to four times more than adults (Torun \&Arica, 2011; Marelli \& Vakulenko, 2014; Ukwayi, Angioha, \& Ojong-Ejoh, 2018; Omang, Liu, Wang, Eneji, Makundi, \& Eneji, 2011). In Africa, of the estimated 420 million youth population aged 15 to 35, more than one third are unemployed, and another third are vulnerably underemployed. Just one in every six youth is in wage employment (African Development Bank, 2018; Ongbali, Afolalu \&Udo, 2019; Attah, Omang, Ojong-Ejoh, \& Botchway, 2021; Omang, 2020). Data from the International Labour Organization (2018) revealed that youth unemployment in sub-Saharan Africa hovers around 12 per cent. The region has the highest working poverty rate, with the most employed individuals working and earning less than two dollars a day. The data also revealed that of the 38.1 per cent of the working poor in Sub-Saharan Africa, The youths account for 23.5 per cent, and young females are at more disadvantage than males (Iloh, 2018; Omang, Okpa, Okoi, \& Iniama, 2020). The report by the African Development Bank (2019) argued that 10 to 12 million youth enter the labour market each year, but only approximately 3.1 jobs are created yearly. The consequence of the unemployment situation of youth in Africa nations is severe and pervasive, translating to poor living conditions, brain drain out of Africa and the continuous conflicts in countries that make up the continent.

In Nigeria, unemployment, underemployment has enveloped the Nigerian labour market. This is compounded by the growing number of graduates, who leave tertiary institutions, every year (Onah \& Okunosa, 2016; Angioha, Nwagboso, Ironbar \& Ishie, 2018; Ojong-Ejoh, Iji \& Angioha, 2019; Attah, Iji, \& Angioha, 2019; Angioha, \& Ugal, 2019). The

\footnotetext{
* Corresponding author.

E-mail address: omangta@gmail.com (Thomas Achoda Omang)
} 
International Labor Organization (2019) estimates that youth unemployment in Nigeria was almost 20 per cent in 2019. According to the National Bureau of Statistics (2019), unemployment in Nigeria stands at 23.1 per cent and underemployment at 16.6 per cent. The World Bank (2018) named Nigeria as the poverty capital of the world, as a result of unemployment, and this has a concomitant effect on the nation, with a high rate of crime and criminality showing itself in the form of insurgency, militancy, arm robbery and drug abuse.

All over the world, scholars, social scientists and policymakers have agreed that entrepreneurship is an essential mechanism for poverty and unemployment reduction (Akin, Onoja \&Kumananza, 2016; Teru, 2015; Abayomi, Angioha, \& Abang, 2021). Entrepreneurship is the most critical player in modern-day economics, especially in developing nations (Assan, 2014). Entrepreneurship advances innovation solves unemployment and underemployment by creating new jobs and satisfying consumers demands. According to Teru (2015), a nation's ability to develop a new stream of business opportunity that creates employment and reduce underemployment drastically come about when people takes to entrepreneurship endeavours. Abdullahi (2009) sees entrepreneurship as the vehicle to improve life's sustainability for individuals and families and sustain and develop a healthy society. Despite the increasing recognition of the importance and role of entrepreneurship as a vehicle for employment generation. The public sector remains the highest employer of labour in developing nations such as Nigeria. It continues to account for 60 to 80 per cent of the total employment creator in In Nigeria (Kalagbo \& Harry, 2019; Ojong-Ejoh, Angioha, Agba, Aniah, Salimon, \& Akintola, 2021).

Successive regimes in Nigeria have made frantic efforts towards entrepreneurship development, but with minimal success, as unemployment and underemployment remain a scourge in Nigeria. In Calabar South, one half of the capital of Cross River state, the youth are confronted with the issue of unemployment, as they form the highest composition of unemployed and underemployed (NBS, 2017). Data from the National Bureau of Statistics revealed that Youths Unemployment Rate stands at 83 per cent, and the educated rate of the youth to the uneducated rate of the youth stands at 61 per cent to 39 per cent (NBS. 2017). These statistics imply that the most educated youth in the local government are not employed. The greatest challenge posed by this situation is the youths being used by politicians as thugs and them engaging in cult-related activities. Deprived of employment opportunities and any source of income, the youths engage in criminal activities to survive. This brings to mind the need for entrepreneurship opportunities. This study examines the relationship between entrepreneurship opportunities and youth employment and underemployment in Calabar South Local Government Area of Cross River State, Nigeria. Specifically, the study.

i. Examines the correlation between poultry farming and youth employment in Calabar.

ii. Assess the relationship between real estate business and youth employment in Calabar

\section{Materials and Method}

\subsection{Population and Sampling}

Cross-Sectional method based on primary was adopted in collecting data from the study area. The target population are youths between the ages of 21 and 35 engaged in entrepreneurship activities in Calabar, Cross River State, Nigeria. Because it is difficult to find the exact number of youths involved in real estate and poultry farming in Calabar, a sample size of 283 was used for the study. To select the samples, Calabar was stratified into two strata based on the local Government areas that are in Calabar. To determine the sample subject to respond to the instrument, three political wards were conveniently selected from the two Local Government Area Calabar. From the three wards set, snowballing sampling technique was used to determine 283 youths engaged in poultry farming and 283 youths involved in real estate.

\subsection{Measurement Instrument}

A self-designed structured questionnaire was developed to assess the entrepreneurship activities of youths in Calabar. Since the variables under study require two separate subjects to respond to it, two different instruments were developed. 
Each questionnaire instrument consists of 10 statements. Each instrument statement relates to the two entrepreneurship variables under study. The questionnaire instrument was constructed in a four-point Likert Scale format that ranges from "1=Strongly Agreed" to "4= Strongly Disagreed". The measuring statements were developed in simple "layman" English to enable the least academic subject to attempt them. The instruments were distributed and retrieved in three months using the self-administered survey between June and August 2021.

\subsection{Instrumentation and Method of Data Analysis}

Data used for this study was gathered from both structured questionnaires. The questionnaire was structured in a four Likert Scale format, designed to accommodate strongly agreed, Agreed, Disagreed and strongly disagreed. It was divided into three sections. Data collected from the field were collated, coded and the appropriate statistical tools were applied. The data was analyzed hypothesis by hypothesis at a significant level of 0.05 . From the 384 questionnaires distributed, only 379 questionnaires were returned without mutilation or missing, and this number was used for analysis.

\section{Analysis and Results}

\subsection{Descriptive Analysis Result}

The data collected were first analyzed using relative frequency and tabular analysis measures to analyze the two entrepreneurship predictors and their relationship with youth employment. All the data generated are considered youths' experiences in the study area. Table 1 to 4 depicts the analyzed response of the study subjects on the questionnaire distributed to them.

The first analysis analyzed how poultry farming correlates with youth employment.

Table 1: Percentage distribution of respondents by views on the number of years engaged in poultry farming

\begin{tabular}{lcc}
\hline \multicolumn{1}{c}{ How long have you engaged in poultry farming } & Frequency & Percentage $(\boldsymbol{\%})$ \\
\hline Inside a year & 97 & 35.9 \\
2 to 3 years & 86 & 31.9 \\
4 to 5 years & 42 & 15.5 \\
6 yrs. and above & 45 & 16.7 \\
\hline Total & $\mathbf{2 7 0}$ & $\mathbf{1 0 0 . 0}$ \\
\hline
\end{tabular}

Table 2: Percentage Distribution of Responses on poultry farming and youth employment

\begin{tabular}{|c|c|c|c|c|c|}
\hline $\mathrm{S} / \mathrm{N}$ & Items & $\begin{array}{c}\text { Strongly } \\
\text { agreed }\end{array}$ & Agreed & Disagreed & $\begin{array}{c}\text { Strongly } \\
\text { disagreed }\end{array}$ \\
\hline 1 & $\begin{array}{l}\text { People are beginning to realize that there } \\
\text { are a lot of opportunities in poultry } \\
\text { farming }\end{array}$ & $\begin{array}{c}111 \\
(41.11)\end{array}$ & $\begin{array}{c}78 \\
(28.90)\end{array}$ & $\begin{array}{c}57 \\
(21.11)\end{array}$ & $\begin{array}{c}24 \\
(8.90)\end{array}$ \\
\hline 2 & $\begin{array}{l}\text { A lot of youths are now engaged in poultry } \\
\text { and livestock production }\end{array}$ & $\begin{array}{c}94 \\
(34.81)\end{array}$ & $\begin{array}{c}98 \\
(36.29)\end{array}$ & $\begin{array}{c}41 \\
(15.20)\end{array}$ & $\begin{array}{c}37 \\
(13.70)\end{array}$ \\
\hline 3 & $\begin{array}{l}\text { Poultry farming is a very profitable } \\
\text { venture }\end{array}$ & $\begin{array}{c}128 \\
(47.40)\end{array}$ & $\begin{array}{c}91 \\
(33.70)\end{array}$ & $\begin{array}{c}33 \\
(12.22)\end{array}$ & $\begin{array}{c}18 \\
(6.66)\end{array}$ \\
\hline 4 & $\begin{array}{l}\text { As a poultry entrepreneur, do you agree } \\
\text { that youths should be engaging more in } \\
\text { poultry }\end{array}$ & $\begin{array}{c}88 \\
(32.50)\end{array}$ & $\begin{array}{c}82 \\
(30.37)\end{array}$ & $\begin{array}{c}66 \\
(24.44)\end{array}$ & $\begin{array}{c}34 \\
(12.50)\end{array}$ \\
\hline 5 & $\begin{array}{l}\text { Engaging in poultry farming has created } \\
\text { means of employment }\end{array}$ & $\begin{array}{c}112 \\
(41.50)\end{array}$ & $\begin{array}{c}87 \\
(32.22)\end{array}$ & $\begin{array}{c}45 \\
(16.66) \\
\end{array}$ & $\begin{array}{c}26 \\
(9.62) \\
\end{array}$ \\
\hline
\end{tabular}


Tables 1 and 2 summarize the data collected on entrepreneurship activity variables, poultry farming and youth employment. Overall, youth involvement in poultry farming has increased over five years, as shown. 25.9 per cents of the study subjects have been engaged in poultry farming inside a year. 31.9 per cent have been engaged in poultry between two and three years. 15.5 per cent have been engaged in poultry between four and five years, with 16.7 per cent engaging in poultry for more than six years. Most of the study subjects reported that 70.01 per cent agreed that there is the realization that there are a lot of opportunities in poultry farming, while 30.01 per cent disagreed. Also, 71.10 per cent of the study subjects agreed that youths are now engaging in poultry and livestock farming, while 28.90 per cent disagreed. In the same vein, 81.10 per cent agreed that engaging in the poultry business is profitable, while 18.88 per cent disagreed. 62.87 per cent agreed that more youths should be engaged in poultry, while 36.94 disagreed. Finally, 73.72 per cent agreed that engaging in poultry farming has created means of employment for the youths, while 26.28 per cent disagreed.

The second analysis analyzed the relationship between real estate business and youth employment.

Table 3: Percentage distribution of respondents by views on the number of years engaged in the real estate business

\begin{tabular}{lcc}
\hline \multicolumn{1}{c}{ How long have you been engaged in real estate } & Frequency & Percentage (\%) \\
\hline Inside a year & 17 & 6.30 \\
2 to 3 years & 64 & 23.70 \\
4 to 5 years & 71 & 26.30 \\
6 yrs. and above & 108 & 40.00 \\
\hline Total & $\mathbf{2 7 0}$ & $\mathbf{1 0 0 . 0}$ \\
\hline
\end{tabular}

Table 3: Percentage Distribution of Responses on real estate business and youth employment

\begin{tabular}{llcccc}
\hline S/N & \multicolumn{1}{c}{ Items } & $\begin{array}{c}\text { Strongly } \\
\text { agreed }\end{array}$ & agreed & disagreed & $\begin{array}{c}\text { Strongly } \\
\text { disagreed }\end{array}$ \\
\hline 11 & The real estate business is growing in this & 102 & 86 & 51 & 31 \\
& area & $(37.70)$ & $(31.90)$ & $(18.90)$ & $(11.50)$ \\
12 & A lot of youths are now engaging in the real & 50 & 71 & 64 & 85 \\
& estate & $(18.51)$ & $(26.29)$ & $(23.70)$ & $(31.50)$ \\
13 & The real estate business is very profitable & 135 & 112 & 13 & 10 \\
& & $(50.00)$ & $(41.48)$ & $(4.81)$ & $(3.70)$ \\
14 & Real estate is helping reduce youth & 120 & 110 & 28 & 12 \\
& unemployment in Calabar & $(44.44)$ & $(40.74)$ & $(10.37)$ & $(4.44)$ \\
15 & As a real estate agent, I can provide my & 160 & 72 & 20 & 18 \\
& basic needs & $(59.30)$ & $(26.70)$ & $(7.40)$ & $(6.60)$ \\
\hline
\end{tabular}

Tables 3 and 4 summarize the result from the data collected on entrepreneurship activity variables, real estate agency and youth employment. In all, there has been a significant increase in youth engagement in real estate. According to data gathered, 40.00 per cent of the subject have been engaged in real estate agencies for six years or more. 26.30 per cent have been engaged in real estate for between 4 and 5 years. 23.70 per cent have been involved for between 2 and 3 years, and 6.30 per cent have been involved inside a year. 69.6 per cent of the study subject agreed that real estate is a growing enterprise in Calabar, while 30.4 per cent disagreed. 44.8 per cent of the study subjects agreed that many youths are now engaging in real estate agencies, while 55.2 per cent disagreed. 91.50 per cent of the subjects agreed that real estate agency is very profitable, while 8.51 per cent disagreed. 85.18 per cent of the subject agreed that real estate is helping reduce unemployment in Calabar, while 14.81 per cent disagreed. Finally, 80.00 per cent of the subjects reported that as real estate agents, they could provide their basic needs, while 14.00 per cent disagreed. 


\subsection{Parametric Statistics}

\subsubsection{Hypothesis One}

Stated in the null form, the first hypothesis states that are no significant correlation between poultry farming and youth employment in Calabar. Linear regression was adopted to analyze the data. The data was derived from the result of the descriptive analysis. In this analysis, the independent variable is poultry farming, and the dependent variable is youth. Both independent and dependent variables were measured continuously at 0.05 alpha level.

Table 5: Summary Simple Linear Regression Analysis of Contribution of Poultry farming to Youth employment

\begin{tabular}{lcc}
\hline Variables & Mean & $\begin{array}{c}\text { Std. } \\
\text { Deviation }\end{array}$ \\
\hline Poultry Farming & 15.0076 & 2.41117 \\
Youth Employment & 16.3715 & 2.31111 \\
\hline
\end{tabular}

\begin{tabular}{lcccccccc}
\hline Model & $\begin{array}{c}\text { Sum of } \\
\text { Squares }\end{array}$ & Df & $\begin{array}{c}\text { Mea } \\
\text { Square }\end{array}$ & F & R & $\begin{array}{c}\text { R } \\
\text { Square }\end{array}$ & $\begin{array}{c}\text { Adjust } \\
\text { ed R } \\
\text { Square }\end{array}$ & Sig \\
\hline $\begin{array}{l}\text { Regression } \\
\text { Residual }\end{array}$ & 21.215 & 1 & 21.215 & 14.002 & $.101^{\mathrm{a}}$ & .010 & .008 & $.046^{\mathrm{a}}$ \\
Total & 2072.545 & 268 & 5.301 & & & & & \\
\hline $\mathrm{p}<0.05$ & 2093.761 & 269 & & & & & &
\end{tabular}

As presented in Table 5, the result of the analysis indicates an $\mathrm{r}$-value of $.101^{\mathrm{a}}$. The correlation coefficient is a standardized measure of an observed degree of relationship between variables. It is a commonly used measure of the size of an effect, and that values of \pm .1 represent a small effect, \pm .3 is a medium effect, and \pm .5 is a significant effect. Also, the $\mathrm{R}^{2}$-value of .010 implies that $10 \%$ of total variance explained is accounted for by the predictor variable (poultry farming).

Furthermore, the regression ANOVA revealed that the $\mathrm{F}(1,391)=14.002 ; \mathrm{p}<0.05$, is significant. Thus the null hypothesis was rejected, while the alternate hypothesis was retained. This implies that there is a joint linear association (contribution) of the predictor variable (poultry farming) on youth employment.

The adjusted $\mathrm{R}^{2}$ (.008) shows some shrinkage of the unadjusted value (.010), indicating that the model could be generalized to the population. Based on the results, it was concluded that youth involvement in poultry farming has significantly improved youth employment in Calabar.

\subsubsection{Hypothesis two}

Stated in the null form, the second hypothesis states that are no significant relationship between real estate business and youth employment in Calabar. Linear regression was adopted to analyze the data. The data was derived from the result of the descriptive analysis. In this analysis, the independent variable is poultry farming, and the dependent variable is youth. Both independent and dependent variables were measured continuously at 0.05 alpha level.

Table 6: Summary simple linear regression analysis of the contribution of real estate agency to youth employment

\begin{tabular}{lll}
\hline Variables & Mean & $\begin{array}{l}\text { Std. } \\
\text { Deviation }\end{array}$ \\
\hline Real estate agency & 15.0076 & 2.41117 \\
Youth employment & 16.2316 & 1.62249 \\
\hline
\end{tabular}




\begin{tabular}{lcccccccc}
\hline Model & Sum of Squares & df & $\begin{array}{c}\text { Mean } \\
\text { square }\end{array}$ & F & R & $\begin{array}{c}\text { R } \\
\text { Square }\end{array}$ & $\begin{array}{c}\text { Adjusted } \\
\text { R Square }\end{array}$ & Sig \\
\hline Regression & 29.732 & 1 & 29.732 & 11.600 & $.170^{\mathrm{a}}$ & .029 & .026 & $.001^{\mathrm{a}}$ \\
Residual & 1002.197 & 268 & 2.563 & & & & & \\
Total & 1031.929 & 269 & & & & & & \\
\hline
\end{tabular}

$\mathrm{p}<0.05$

As presented in table 6 . indicate r-value of $.170^{\mathrm{a}}$. The correlation coefficient is a standardized measure of an observed degree of relationship between variables. It is a commonly used measure of the size of an effect, and that values of \pm .1 represent a small effect, \pm .3 is a medium effect, and \pm .5 is a significant effect. Also, the $\mathrm{R}^{2}$-value of .029 implies that $29 \%$ of total variance explained is accounted for by the predictor variable (real estate agency).

Furthermore, the regression ANOVA revealed that the $\mathrm{F}(1,391)=11.600 ; \mathrm{p}<0.05$, is significant. Thus, the null hypothesis was rejected, while the alternate hypothesis was retained. This implies that there is a linear association (contribution) of the predictor variable (real estate agency) on youth employment.

The adjusted $\mathrm{R}^{2}(.026)$ shows some shrinkage of the unadjusted value (.029), indicating that the model could be generalized to the population. Based on the results, it was concluded the involvement of youths in real estate has improved youth employment in Calabar.

\subsection{Discussion of Findings}

As mentioned, this study assessed entrepreneurship opportunities as a catalyst for youth employment. Two entrepreneurship opportunities (poultry farming and real estate agency) were examined. Two different instruments were formulated and distributed to 566 youths ( 283 devices for poultry farmers and 283 for real estate agents) engaged in poultry farming and real estate agency in Calabar, Cross River State. Out of the distributed instruments distributed and returned, 270 were considered good enough for each and were used for analysis.

In the first analysis, Simple linear regression was used to analyze the correlation between poultry farming and youth employment. There was a considerable correlation between the predictor variable (poultry farming) and the independent variable from the analysis. The model explains 10 per cent of the predictor's variance on youth employment. As indicated by the first objective, the questions raised from it and the descriptive and parametric statistics youths attitude towards engaging in poultry activity has helped reduce the problem of unemployment in Calabar. The earning power, lack of other sources of income, improving youths quality of life and the ability to provide basic needs and the primary driving force of engaging in poultry farming. From the descriptive analysis, 81.10 per cent of the subjects reported that poultry farming is very profitable, and 73.72 per cent reported that engaging in poultry has created an alternative source of employment. As suggested by the study of Ajala, Ogunjimi, Famuwagun, and Adebimpe (2021), poultry farming can be exploited and harnessed by the youths for empowerment and employment creation. Gueye (2002) asserts that poultry farming is an appropriate source of protein and can provide employment or alternative source of income for low-income households. The study of Bounds and Zinyemba (2018) found that involvement in chicken farming can alleviate rural poverty and unemployment.

In the second analysis, simple linear regression was also used to check the relationship between real estate business and youth employment. The analysis shows a linear association (contribution) of the predictor variable (real estate agency) on youth employment. Also, the $\mathrm{R}^{2}$-value of .029 implies that $29 \%$ of total variance explained is accounted for by the predictor variable (real estate agency). Most of the study subjects (91.50\%) agreed that real estate is profitable from the descriptive analysis. 44.8 per cent reported that many youths are now engaging in real estate. A large per cent of the $(85.18 \%)$ reported that real estate is helping reduce unemployment in Calabar. With this result, we can conclude that the involvement of youths in real estate has improved youth employment in Calabar.

With this result, we can conclude that entrepreneurship opportunity helps reduce youth unemployment in Calabar. 


\section{Conclusion and Policy Implication}

The situation of youth unemployment in Calabar is and all known avenue and traditional means of creating work for the increasing youth population. The prospect of gaining employment for the average youth in Calabar and the country is bleak, and the situation worsens every day. The issue poses a danger to the nation' development and security. Hence, there is need for the government to periodically implement various skill acquisition programs, where entrepreneurship skills and other vocation training are taught, and practical participation will be carried out. Also, Nigeria is predominantly an agricultural nation. Therefore, agriculture should be at the forefront of the nation's development policy. The country's agriculture sector should be promoted through incentive packages such as soft loans without collateral and minimal interest rate as well as other packages.

\section{References}

Abayomi, A., Angioha, P. U., \& Abang, T. (2021). Covid 19 Pandemic and Entrepreneurship Enterprise in Calabar, Cross River State, Nigeria. Journal of Good Governance and Sustainable Development in Africa, 6(1), 23-29.

Abdullahi S. (2009). The transformation from entrepreneurship to technology entrepreneurship development in Malaysia. J. Chinese Entrep.1(3):240 -247

African Development Bank (2019). Jobs for Youth in Africa. Catalyzing youth opportunity across Africa. A report

Ajala, A. O., Ogunjimi, S. I., Famuwagun, O. S., \& Adebimpe, A. T. (2021). Poultry production in Nigeria: exploiting its potentials for rural youth empowerment and entrepreneurship. Nigerian Journal of Animal Production, 48(1), 114-123. https://doi.org/10.51791/njap.v48i1.2890

Akiri, S. E., Onoja, E., \& Kunanzang, P. S. (2016). Entrepreneurship and Job Creation in Nigeria. IIARD International Journal of Economics and Business Management. 2 (3), 61-67.

Angioha, P. U., \& Ugal, B. U. (2019). Information and Communication Technology and Youth Employment in Calabar Municipality, Cross River State, Nigeria. International Journal of Research and Innovation in Social Science (IJRISS), 3(2), 2454-6186.

Angioha, P. U., Nwagboso, S. N., Ironbar, A. E. \& Ishie, E. U. (2018). Underemployment: A Sociological and Policy Analysis of Workers Well-Being in Hospitality Industry in Calabar South Local Government Area, Cross River State, Nigeria. IOSR Journal of Humanities and Social Science (IOSR-JHSS), Volume 23, Issue 6, Ver. 5 (June. 2018) PP 57-66.

Attah, F. M., Omang, T. A., Ojong-Ejoh, M. U., \& Botchway, H. (2021). Information on the Impact National N-Power Scheme on Employment Creation. JINAV: Journal of Information and Visualization, 2(1), 42-49.

Attah, F., Iji, M. E., \& Angioha, P. U. (2019). Associate factors affecting the growth of micro business in Calabar, Cross River State, Nigeria. European Journal of Human Resource Management Studies.

Bounds, M., \& Zinyemba, O. (2018). Poultry farming: Lessening poverty in rural areas. South African Journal of Agricultural Extension (SAJAE), 46(1). https://doi.org/10.17159/2413-3221/2018/v46n1a436

Guèye, E. (2002). Employment and income generation through family poultry in low-income food-deficit countries. World's Poultry Science Journal, 58(4), 541-557. https://doi.org/10.1079/wps20020039

ILO. (2019). World Employment and Social Outlook - Trends 2019 - ILO 
Kalagbor, S. B. \& Harry, D. M. (2019). Entrepreneurship Development and Youth Employment in Nigeria: Perspectives on Selected Entrepreneurship Schemes. International Journal of Small Business and Entrepreneurship Research. 7, (5), pp.31-42

Marelli E. \& Vakulenko E. (2014), 'Youth Unemployment in Italy and Russia: Aggregate Trends and The role of Individual Determinants', National Research University Higher Scholl of Economics Working Paper, WP BRP 74/EC/2014, 1-31.

Ojong-Ejoh, M. U., Angioha, P. U., Agba, R. U., Aniah, E. A., Salimon, M. G., \& Akintola, A. (2021). Operating SMEs in the Face of the Covid-19 Pandemic in Calabar. Quantitative Economics and Management Studies, 2(4), $272-280$

Ojong-Ejoh, M. U., Iji, M. E., Angioha, P.U. (2019).Curing Socio-Economic ILLS in Obudu Local Government Area: An Assessment of Non-Governmental Agencies Activities". Journal of Social Service and Welfare;1(2): 3845.

Omang, T. A., Liu, Y., Wang, Y., Eneji, R. I., Makundi, J. J., \& Eneji, A. M. (2011). Impacts of Poverty Reduction Programmes in Nigeria: The Case of the Youth Empowerment Scheme (YES) in Cross River State. Annals of Humanities and Development Studies, 2(1), 33-50.

Omang, T. A., Okpa, J. T., Okoi, O. N., \& Iniama, J. (2020). Women Barriers and Empowerment Opportunities in The Nigerian Context. Pertanika Journal of Social Sciences and Humanities, 28(4). https://doi.org/10.47836/pjssh.28.4.37

Onah N.G. \& Okwuosa L.N. (2016) Youth Unemployment and Peace in Nigeria Society. Mediterranean Journal of Social Sciences, 7 (1)

Ongbali, S. O., Afolalu S. A \& Udo M. O. (2019). Factors Causing Youth Unemployment Problem in Nigeria: A Review, International Journal of Mechanical Engineering and Technology, 10(01), pp.1847-1879

Teru, S. P. (2015). Evaluation of the Impact of Entrepreneurship on Nigerian Economic Development (A Case Study of Jalingo Local Government Area of Taraba State, Nigeria). Pearl Journal of Management, Social Science and Humanities, 1 (4), pp. 69-77

Torun M., Arıca F. (2011), '2008 Global Economic Crisis And Its Effects On Youth Unemployment, ÇOMU Journal of Administrative Sciences, 9(1), 164-177.

Ukwayi, J. K., Angioha, P. U., \& Ojong-Ejoh, M. U. (2018). Youth empowerment: A criminological approach for crime prevention and control in Cross River State, Nigeria. IOSR Journal of Humanities and Social Science (IOSRJHSS), 22(11), 73-81.

World Bank, (2004). Partnership in development: progress in the fight against poverty. Washington DC: World Bank 